\title{
A facile one step synthesis of $N$-2 substituted 3-phenyliminoisoindolinones from $N$-(2-carboxybenzoyl)-anthranilic acid and the design of reverse-turn mimetics
}

\author{
Pradyot Koley, ${ }^{a}$ Arpita Dutta, ${ }^{a}$ Michael G. B. Drew, ${ }^{b}$ Sudeshna Kar, ${ }^{a}$ and Animesh \\ Pramanik $^{a_{*}}$ \\ ${ }^{a}$ Department of Chemistry, University of Calcutta, 92, A. P. C. Road, Kolkata-700 009, India \\ ${ }^{b}$ School of Chemistry, The University of Reading, Whiteknights, Reading, UK RG6 6AD \\ E-mail: animesh_in2001@yahoo.co.in
}

\begin{abstract}
Stirring of $N$-(2-carboxybenzoyl)anthranilic acid with anilines and amines such as $p$-toluidine, benzylamine, methyl esters of Leu, Phe, Ile and Val in presence of DCC produces $N-2$ substituted 3-phenyliminoisoindolinones in very good yields. Single crystal X-ray diffraction studies and solution phase NMR and CD studies reveal that the 3-phenyliminoisoindolinone moiety is a turn-inducing scaffold which should be useful for reverse-turn mimetics.
\end{abstract}

Keywords: $N$-(2-Carboxybenzoyl)anthranilic acid, 3-phenyliminoisoindolinones, amino acids, DCC mediated coupling, reverse-turn mimetics

\section{Introduction}

Generally 3-iminoisoindolinone derivatives are pigments with excellent color strength and suitable for pigmenting organic materials of high molecular weight, such as ethyl cellulose, acetyl cellulose, nitrocellulose, polyamide, polyester, natural resins and synthetic resins. ${ }^{1}$ Further iminoisoindolinones are used to prepare nanosized organic pigments which are used effectively as additives for crystal growth during pigment synthesis. ${ }^{2} 3$-Iminoisoindolinone itself is found to form inclusion complexes with $\beta$ - and $\gamma$-cyclodextrins. ${ }^{3}$ Interestingly it has been observed that 3 iminoisoindolinone can bind to an enzyme possessing $N$-iminylamidase activity isolated from pig liver. ${ }^{4}$ Although 3-iminoisoindolinone and its derivatives are important for diverse kinds of applications, there has been only a limited number of methods available in the literature for their synthesis. As for example iminoisoindolinone pigments are obtained by condensation of suitably substituted isoindolinones with diamines. ${ }^{1,2}$ The synthesis of 3-phenyliminoisoindolinone is achieved by refluxing 1 -amino-3-phenyliminoisoindoline with phthalonitrile. ${ }^{5}$ In this report we 
wish to present a general and efficient method for the synthesis of $\mathrm{N}-2$ substituted 3phenyliminoisoindolinones from easily prepared $N$-(2-carboxybenzoyl)anthranilic acid.

It is well established that reverse-turns play important roles in stabilizing tertiary structures, initiating folding and facilitating intermolecular recognition. ${ }^{6}$ There have been increasing efforts to rationally design and synthesize biologically active non-peptidic analogues of peptide reverse turns. ${ }^{7}$ Since enzymes like mammalian imidase recognizes 3 -iminoisoindolinone as substrate for hydrolysis, ${ }^{4}$ it will be quite pertinent to design reverse turns on a 3-iminoisoindolinone scaffold. They will provide an opportunity to explore the substrate specificity, chemoselectivity and the mechanism of enzymatic hydrolysis of compounds bearing the $N$-iminylamide functional group.

\section{Results and Discussion}

Initially we thought that $N$-(2-carboxybenzoyl)anthranilic acid $\mathbf{1}$, the alkaline hydrolysis product of 2-phthalimidobenzoic acid, ${ }^{8}$ could be a reverse-turn inducing scaffold. Therefore, we were trying to develop reverse-turn mimetics through DCC mediated coupling of $\mathbf{1}$ with various anilines, amines and amino acids. Surprisingly we observed that stirring of $\mathbf{1}$ with $p$-toluidine in the presence of DCC in DMF produces an unusual product $\mathrm{N}-2$ substituted 3phenyliminoisoindolinone 2a in very good yield (Scheme 1, Table 1, Entry 1). Under similar conditions, $\mathbf{1}$ also produces $\mathbf{2 b}$ by reaction with benzylamine (Entry 2). We have proposed a mechanism for this reaction. The intermediate 3 which is formed through the DCC mediated coupling of 1 with $p$-toluidine and benzylamine, undergoes intramolecular nucleophilic attack of the amide NH to the phthalamide $\mathrm{CO}$ to produce the isoindolinone based intermediate 4. Subsequently dehydration produces the final compounds $\mathbf{2 a}$ and $\mathbf{2 b}$. Previous reports show that 3-phenyliminoisoindolinone can be prepared by refluxing 1-amino-3-phenyliminoisoindoline with phthalonitrile. ${ }^{5}$ Synthesis of compounds $\mathbf{2 a}$ and $\mathbf{2 b}$ by this method is not straightforward. Some synthetic optimization is necessary to achieve the target. The present method represents a novel one step reaction to derive $N-2$ substituted 3-phenyliminoisoindolinones such as $2 \mathbf{a}$ and $\mathbf{2 b}$ starting from 1.

The formation $\mathbf{2 a}$ and $\mathbf{2} \mathbf{b}$ in the above method indicates that the natural L- $\alpha$-amino acids would be good candidates for reaction with $\mathbf{1}$ in a similar fashion to provide a useful route to achieve reverse-turn mimetics on the basis of a 3-phenyliminoisoindolinone scaffold. In fact, the DCC mediated coupling of $\mathbf{1}$ with methyl esters of various amino acids such as Leu, Phe, Ile and Val produces 3-phenyliminoisoindolinones 2c-f in very good yields (Scheme 1, Table 1, Entry 36). The structures of compounds 2 a-f were confirmed by their IR, ${ }^{1} \mathrm{H} N M R$, and ${ }^{13} \mathrm{C} N M R$ spectra. The X-ray crystal structures of $\mathbf{2 c}$ and $\mathbf{2 d}$ further confirm the product formation. ${ }^{9,10}$ The formation of 2a-f through the coupling of $\mathbf{1}$ with $p$-toluidine, benzylamine and various amino acids demonstrates the synthetic potential and generality of the present method.

The DCC mediated reaction of 1 with anilines containing electron withdrawing groups such as methyl $m$-aminobenzoate and $p$-nitroaniline produces different products $\mathbf{5 a}$ and $\mathbf{5 b}$ (Scheme 2, 
Table 1, Entry 7 and 8). Since the coupling of methyl $m$-aminobenzoate and $p$-nitroaniline with 1 is slow, the intermediate 2-phthalimidobenzoic acid $\mathbf{6}$ is formed in a higher rate than intermediate 3 . Finally coupling of $\mathbf{6}$ with anilines produces $\mathbf{5 a}$ and $\mathbf{5 b}$ (Scheme 2).<smiles>[R]NCC(C)(C)N</smiles>

1<smiles>[R]NC(=O)c1ccccc1/N=C1\c2ccccc2C(=O)N1[R]</smiles>

2a-f

2a: $\mathrm{R}: \xi-\mathrm{CH}_{3}$<smiles>[R]C([R])([14CH3])Cc1ccccc1</smiles><smiles>[R]CC(C)[C@H](C)C(=O)OC</smiles><smiles>[R]NC(=O)c1ccccc1NC(=O)c1ccccc1C(=O)N[R]</smiles>

3<smiles>[R]NC(=O)c1ccccc1NC1(O)c2ccccc2C(=O)N1[R]</smiles>

2d: $\mathrm{R}$ :<smiles>COC(=O)[C@H](C)Cc1ccccc1</smiles>

2e: $R$ :<smiles>CCC(C)[C@H](C)C(=O)OC</smiles>

2f: $R$ :

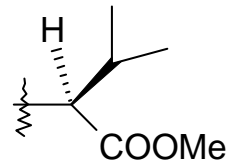

\section{Scheme 1}


Table 1. Formation of $\mathbf{2}$ and $\mathbf{5}$ from N-(2-carboxybenzoyl)anthranilic acid $\mathbf{1}$

\begin{tabular}{ccccc}
\hline Entry & $\mathrm{R}_{\mathrm{NH}}$ & Products & $\mathrm{Yields}^{\mathrm{a}}(\%)$ & $\mathrm{Mp}\left({ }^{0} \mathrm{C}\right)^{\mathrm{b}}$ \\
\hline 1 & p-toluidine & 2a & 85.0 & 280 \\
2 & benzylamine & 2b & 82.5 & 206 \\
3 & methyl ester of L-Leu & 2c & 90.2 & 148 \\
4 & methyl ester of L-Phe & 2d & 94.2 & 165 \\
5 & methyl ester of L-Ile & 2e & 87.3 & 146 \\
6 & methyl ester of L-Val & 2f & 83.0 & 149 \\
7 & methyl $m$-aminobenzoate & $\mathbf{5 a}$ & 80.6 & 238 \\
8 & -nitroaniline & $\mathbf{5 b}$ & 70.5 & 182 \\
\hline
\end{tabular}

${ }^{a}$ Yields refer to pure isolated products.

${ }^{b}$ MPs are uncorrected.

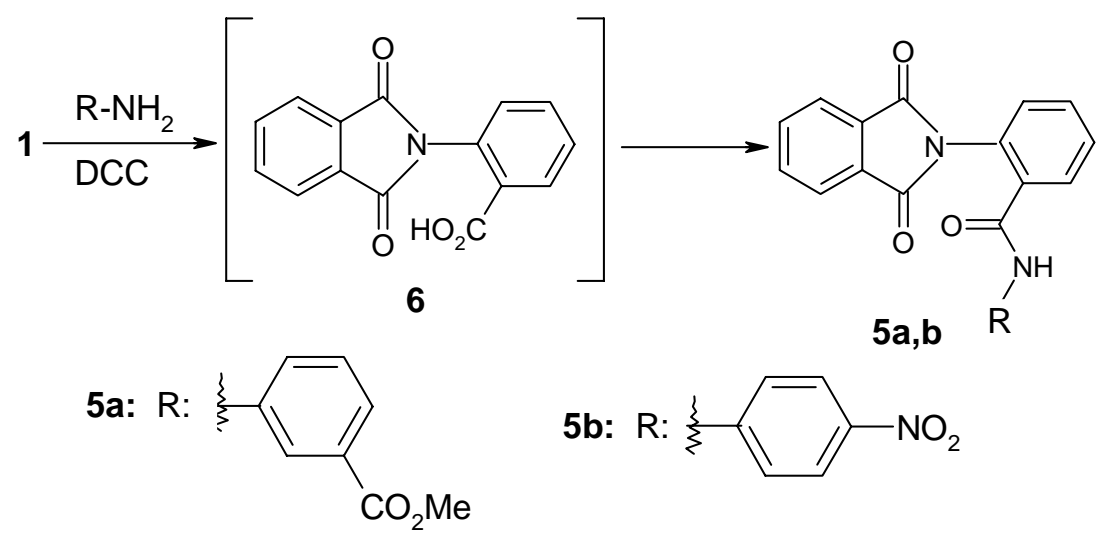

\section{Scheme 2}

Single crystal X-ray diffraction studies show that both $\mathbf{2 c}$ and $\mathbf{2 d}$ adopt turn structures around the central 3-phenyliminoisoindolinone scaffold (Figures 1 and 2). Although a previous report showed that 3-phenyliminoisoindolinone prefers the anti conformation in the solid state, ${ }^{5}$ in $2 \mathrm{c}$ and 2d the centrally placed 3-phenyliminoisoindolinone moiety adopts the syn conformation. This helps 2c and $\mathbf{2 d}$ to attain a turn structure around the imino $\mathrm{C}=\mathrm{N}$ bond. The torsion angle $\mathrm{C}(41)-\mathrm{N}(51)-\mathrm{C}(52)-\mathrm{N}(10)$ is $-5.2(2)^{\circ}$ at iminoisoindolinone moiety and $\mathrm{N}(10)-\mathrm{C} 9-\mathrm{C} 4-\mathrm{C} 3=$ $7.1(2)^{\circ}$ at the anthranilic acid moiety are responsible for inducing a turn structure in $\mathbf{2 c}$ (Table 2). The corresponding torsion angles values $0.9(4)^{\circ}$ and $3.0(4)^{\circ}$ in $\mathbf{2 d}$ ensure a turn conformation. A $\beta$-turn is defined as a tetrapeptide sequence in which the $\alpha$-carbon distance between first and fourth residue is less than $7 \AA .{ }^{11}$ Crystal structure analysis reveals that the distance between the $\alpha$-carbon atoms (between $C(41)$ and $C(1)$ ) in $2 \mathbf{c}$ and $2 \mathbf{d}$ are 6.32 and $4.95 \AA$ respectively, well within the limit for satisfying the criteria of $\beta$-turn mimetics (Figures 1,2 ). The only major difference in the conformation of the backbone of $\mathbf{2 c}$ and $\mathbf{2 d}$ can be seen in the torsion angle $\mathrm{C}(9)-\mathrm{C}(4)-\mathrm{C}(3)-\mathrm{N}(2)$ which is $-145.3(2)^{\circ}$ in $2 \mathrm{c}$ and $-24.1(4)^{\circ}$ in 2d. Actually this change in 
torsion angle brings $\mathrm{C}(41)$ and $\mathrm{C}(1)$ closer in $\mathbf{2 d}$ than that of in 2c. Both $\mathbf{2 c}$ and $\mathbf{2 d}$ can not form any intramolecular hydrogen bond in the solid state. $\beta$-turns which do not contain hydrogen bonds are generally referred to as open turns. ${ }^{12,13}$

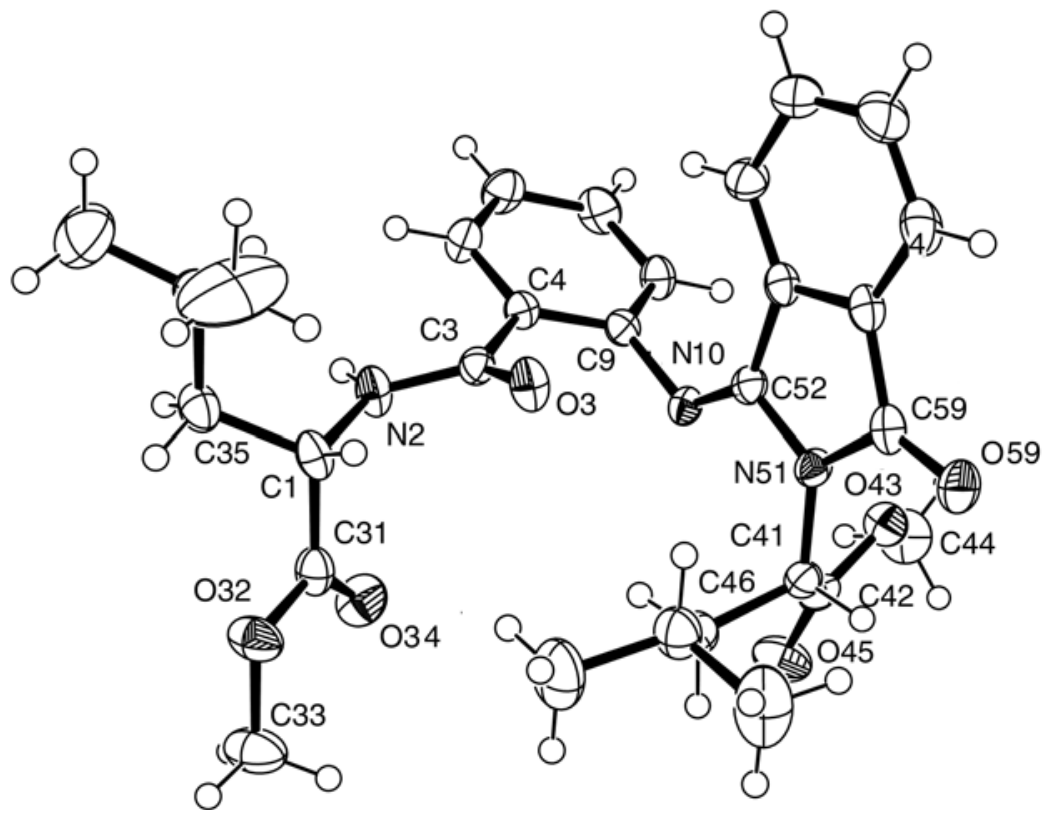

Figure 1. The ORTEP diagram of 2c including atom numbering scheme. Thermal ellipsoids are shown at the level of $50 \%$ probability.

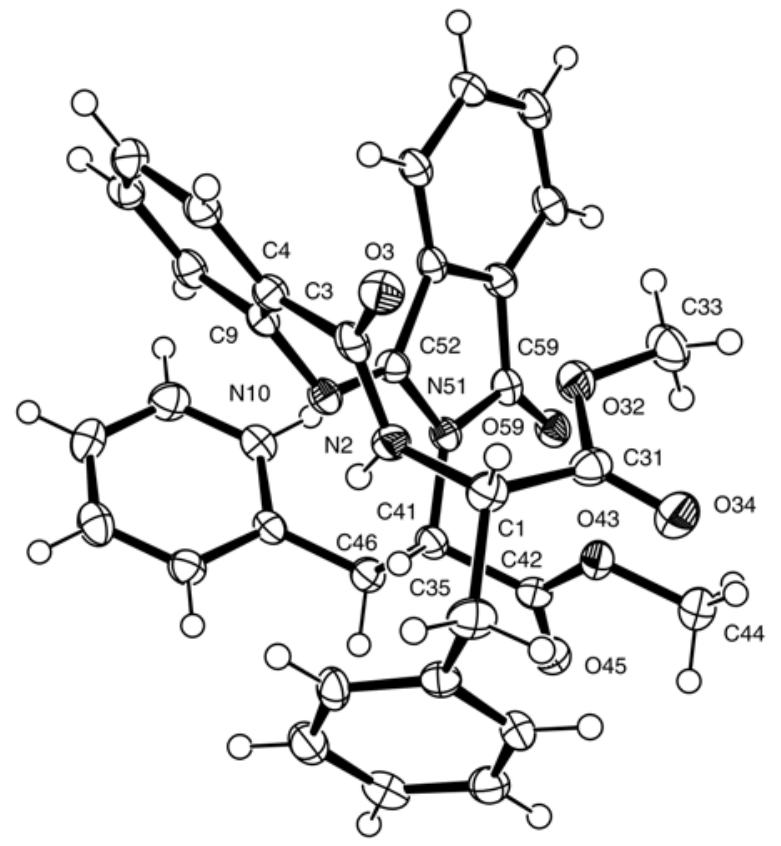

Figure 2. The ORTEP diagram of 2d including atom numbering scheme. Thermal ellipsoids are shown at the level of $50 \%$ probability. 
Table 2. Selected backbone torsion angles $\left({ }^{\circ}\right)$ of pseudopeptides $\mathbf{2 c}$ and $\mathbf{2 d}$ as determined by Xray diffraction studies

\begin{tabular}{ccc}
\hline & 2c & 2d \\
\hline $\mathrm{C}(44)-\mathrm{C}(43)-\mathrm{C}(42)-\mathrm{C}(41)$ & $177.3(2)$ & $177.4(2)$ \\
$\mathrm{C}(43)-\mathrm{C}(42)-\mathrm{C}(41)-\mathrm{N}(51)$ & $31.8(2)$ & $51.3(8)$ \\
$\mathrm{C}(42)-\mathrm{C}(41)-\mathrm{N}(51)-\mathrm{C}(52)$ & $59.9(2)$ & $-136.7(2)$ \\
$\mathrm{C}(41)-\mathrm{N}(51)-\mathrm{C}(52)-\mathrm{N}(10)$ & $-5.2(2)$ & $0.9(4)$ \\
$\mathrm{N}(51)-\mathrm{C}(52)-\mathrm{N}(10)-\mathrm{C}(9)$ & $178.8(2)$ & $-172.6(2)$ \\
$\mathrm{C}(52)-\mathrm{N}(10)-\mathrm{C}(9)-\mathrm{C}(4)$ & $-94.2(2)$ & $-109.7(3)$ \\
$\mathrm{N}(10)-\mathrm{C}(9)-\mathrm{C}(4)-\mathrm{C}(3)$ & $7.1(2)$ & $3.0(4)$ \\
$\mathrm{C}(9)-\mathrm{C}(4)-\mathrm{C}(3)-\mathrm{N}(2)$ & $-145.3(2)$ & $-24.1(4)$ \\
$\mathrm{C}(4)-\mathrm{C}(3)-\mathrm{N}(2)-\mathrm{C}(1)$ & $176.0(2)$ & $167.4(2)$ \\
$\mathrm{C}(3)-\mathrm{N}(2)-\mathrm{C}(1)-\mathrm{C}(31)$ & $-96.9(2)$ & $-94.6(3)$ \\
$\mathrm{N}(2)-\mathrm{C}(1)-\mathrm{C}(31)-\mathrm{O}(32)$ & $-177.2(2)$ & $19.0(3)$ \\
$\mathrm{C}(1)-\mathrm{C}(31)-\mathrm{O}(32)-\mathrm{C}(33)$ & $-178.5(2)$ & $174.1(2)$ \\
\hline
\end{tabular}

In the ${ }^{1} \mathrm{H}$ NMR solvent titration it has been observed that by increasing the percentage of $\left(\mathrm{CD}_{3}\right)_{2} \mathrm{SO}$ in $\mathrm{CDCl}_{3}$ from 0 to $8.1 \%(\mathrm{v} / \mathrm{v})$ the net changes in the chemical shift $(\Delta \delta)$ values for Leu-NH in 2c and Phe-NH in 2d are negligible, 0.00 , and $0.02 \mathrm{ppm}$ respectively (Figure 3). ${ }^{14}$

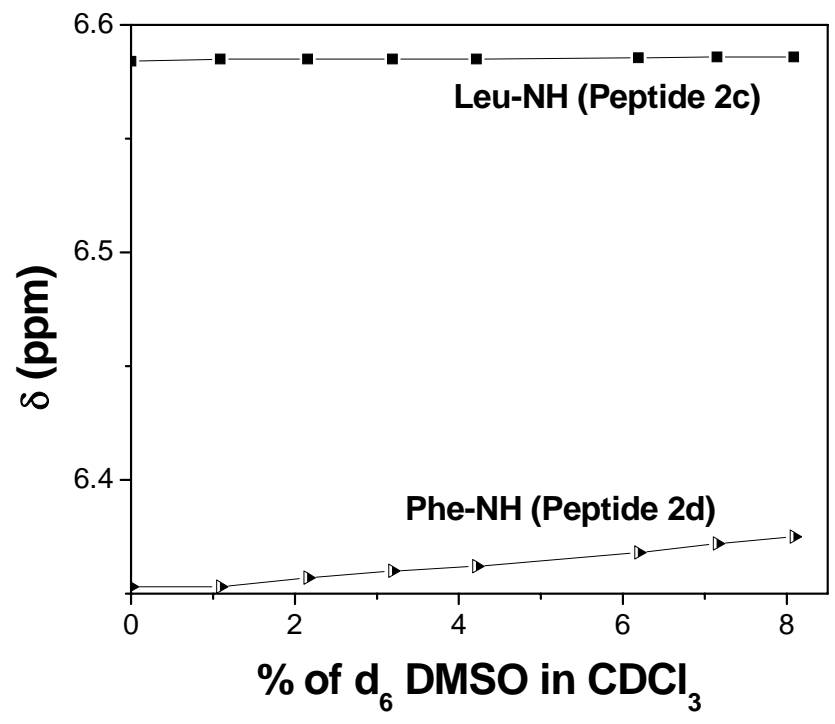

Figure 3. Plot of solvent dependence of $\mathrm{NH}$ chemical shifts ( $\delta$ in ppm) of pseudopeptides $\mathbf{2 c}$ and 2d at varying concentration of DMSO- $\mathrm{d}_{6}$ in $\mathrm{CDCl}_{3}$. 
The result indicates that in the solution phase Leu-NH of 2c and Phe-NH of 2d are strongly hydrogen bonded preferably with the $\mathrm{C}=\mathrm{O}$ of the methyl ester group of the remaining amino acid within the same molecule to stabilize the 11-membered turn structures (Figure 4). Further the ability of 2c and 2d to adopt a turn structure in solution was also evaluated by CD spectroscopy (Figure 5). The spectra were measured in methanol $(1.5 \mathrm{mM})$ and showed a similar behaviour: two negative minima, one at $207-210 \mathrm{~nm}$ and a second one at $230-235 \mathrm{~nm}$ and a positive maximum at 119-223 nm were displayed by both the pseudopeptides $\mathbf{2 c}$ and $\mathbf{2 d}$. The CD pattern is found to be quite similar to that of reported $\beta$-hairpin mimetics containing diketopiperazine as turn inducing scaffold. ${ }^{15}$ Therefore, the results of solvent dependent NMR titrations and CD spectroscopy favor the conclusion that both $\mathbf{2 c}$ and $\mathbf{2 d}$ are folded into turn structures in the solution phase.

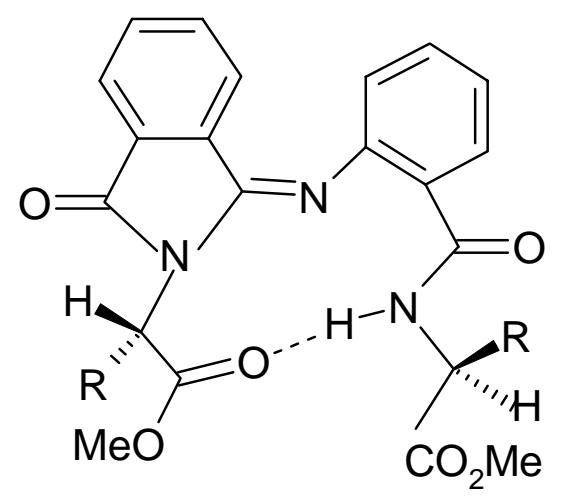

Figure 4. Schematic diagram of intramolecular hydrogen bond of $\mathbf{2 c}$ and $\mathbf{2 d}$ in the solution phase.

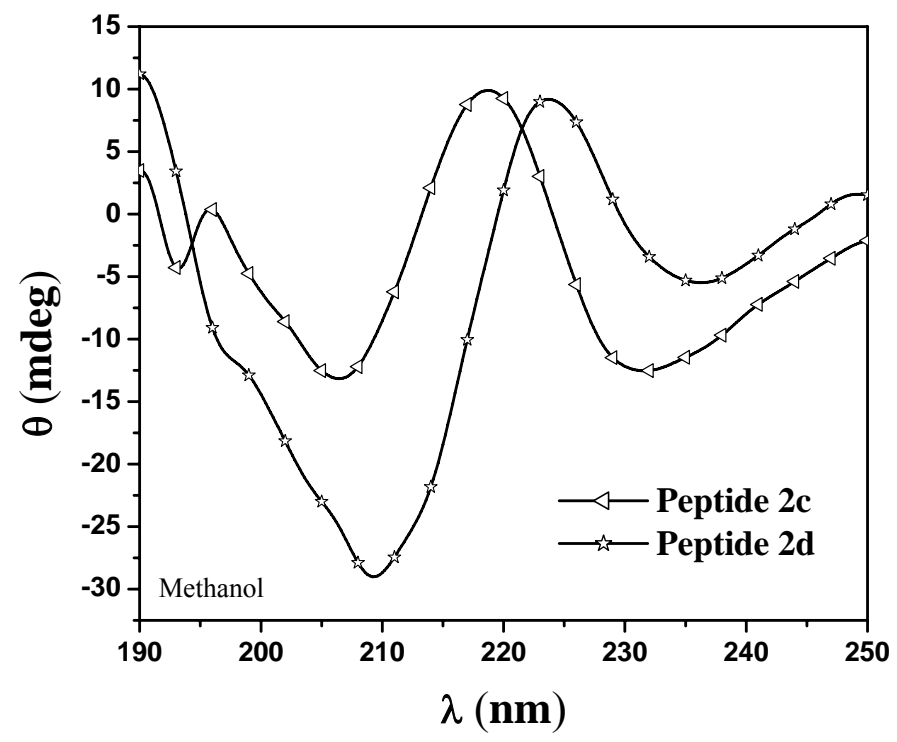

Figure 5. CD spectra of pseudopeptides $2 \mathbf{c}$ and $\mathbf{2 d}$ (1.5 $\mathrm{mM}$ in methanol). 
Generally 3-iminoisoindolinone derivatives are color pigments. ${ }^{1}$ They are also useful for preparing nanosized organic pigments. ${ }^{2}$ In the present study $\mathbf{2 a}$ and $\mathbf{2} \mathbf{b}$ are found to be white. Interestingly all the compounds 2c-f derived from the amino acids are found to be yellow in color. The photograph of yellow crystals of $\mathbf{2 d}$ is presented in Figure 6.

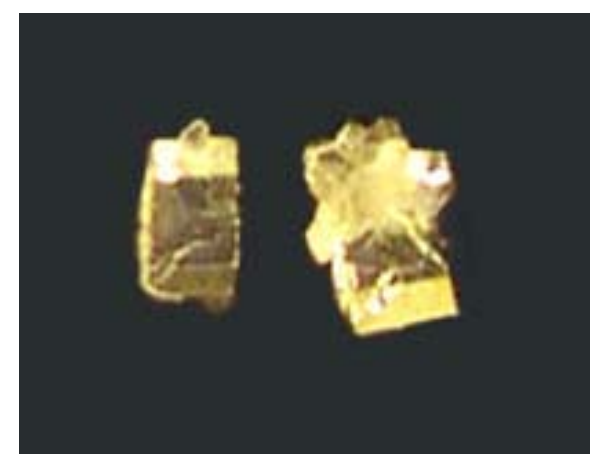

Figure 6. Photograph of the crystals of compound 2d.

\section{Conclusions and out look}

In summary, we have found a general and efficient method for the preparation of $\mathrm{N}-2$ substituted 3-phenyliminoisoindolinones by DCC mediated coupling of $N$-(2-carboxybenzoyl)anthranilic acid with activated anilines, amines and amino acids. The present method is a simple one-step reaction involving easily prepared starting materials. Single crystal X-ray diffraction studies and solution phase NMR and CD studies on two pseudopeptides reveal that 3phenyliminoisoindolinone is a turn-inducing scaffold. Apart from developing reverse-turns this scaffold could be utilized in engineering the turn regions of $\beta$-hairpins and multiple antiparallel $\beta$-strands. The exploration of the substrate specificity, chemoselectivity and catalytic mechanism of hydrolysis of enzyme mammalian imidase ${ }^{4}$ with respect to these turns and hairpins may provide more insights.

\section{Experimental Section}

\section{General procedure for products $2 a$ and $2 b$}

(2.0 g, $7.02 \mathrm{mmol}$ ) of compound $\mathbf{1}$ was dissolved in dimethylformamide (DMF, $8 \mathrm{~mL}$ ). Appropriate anilines and amines such as $p$-toluidine and benzylamine $(42.12 \mathrm{mmol})$ were added to the former solution followed by addition of DCC $(4.34 \mathrm{~g}, 21.06 \mathrm{mmol})$ in an ice-cold condition. The reaction mixture was stirred at room temperature for 1 day. The precipitated dicyclohexylurea (DCU) was filtered off. The filtrate was diluted with ethylacetate. The organic layer was washed with $1 \mathrm{~N} \mathrm{HCl}(3 \times 30 \mathrm{~mL})$, brine, $1 \mathrm{M} \mathrm{Na}_{2} \mathrm{CO}_{3}$ solution $(3 \times 30 \mathrm{~mL})$ and then 
again with brine. The solvent was dried over anhydrous $\mathrm{Na}_{2} \mathrm{SO}_{4}$ and evaporated in vacuo, giving a light yellow gum. The products were purified by column chromatography over silica gel (ethyl acetate-petroleum ether). The final compounds were fully characterized by $300 \mathrm{MHz}{ }^{1} \mathrm{H}$ NMR spectroscopy, $75 \mathrm{MHz}^{13} \mathrm{C}$ NMR spectroscopy, IR spectroscopy.

2a. Elemental analysis calcd for $\mathrm{C}_{29} \mathrm{H}_{23} \mathrm{~N}_{3} \mathrm{O}_{2}(445.52) \mathrm{C}, 78.18 ; \mathrm{H}, 5.20 ; \mathrm{N}, 9.43 \%$. Found: $\mathrm{C}$, 78.05; H, 5.13; N, $9.32 \%$. IR (KBr): 3286, 1664, 1601, 1523, $1471 \mathrm{~cm}^{-1} .{ }^{1} \mathrm{H}$ NMR $300 \mathrm{MHz}$ $\left(\mathrm{CDCl}_{3}, \delta \mathrm{ppm}\right): 8.33(\mathrm{ArH}, 1 \mathrm{H}, \mathrm{dd}, J=8.1,0.6 \mathrm{~Hz}), 7.99(\mathrm{p}$-Toluidine $\mathrm{NH}, 1 \mathrm{H}, \mathrm{s}), 7.80-7.71$ (ArH, 2H, m), 7.59-7.51 (ArH, 2H, m), 7.35-7.26 (ArH, 5H, m), 7.15-7.01 (ArH, 6H, m), 2.29 (p-Toluidine (1) $\left.-\mathrm{CH}_{3}, 3 \mathrm{H}, \mathrm{s}\right), 2.25$ (p-Toluidine (2) $\left.-\mathrm{CH}_{3}, 3 \mathrm{H}, \mathrm{s}\right) ;{ }^{13} \mathrm{C} \mathrm{NMR} 75 \mathrm{MHz}\left(\mathrm{CDCl}_{3}, \delta\right.$ ppm): 165.6, 162.0, 155.4, 147.2, 138.5, 135.3, 135.2, 135.1, 134.7, 134.6, 134.4, 134.2, 130.2, 130.0, 129.6 (2C), 129.3, 128.6 (2C), 127.4 (2C), 127.3 (2C), 126.1, 121.4, 120.4, 120.1, 21.1, 20.8 .

2b. Elemental analysis calcd for $\mathrm{C}_{29} \mathrm{H}_{23} \mathrm{~N}_{3} \mathrm{O}_{2}(445.52) \mathrm{C}, 78.18 ; \mathrm{H}, 5.20 ; \mathrm{N}, 9.43 \%$. Found: $\mathrm{C}$, 78.08; H, 5.09; N, $9.33 \%$. IR (KBr): 3353, 1656, 1596, 1532, $1473 \mathrm{~cm}^{-1}$. ${ }^{1} \mathrm{H}$ NMR $300 \mathrm{MHz}$ $\left(\mathrm{CDCl}_{3}, \delta \mathrm{ppm}\right): 8.36(\mathrm{ArH}, 1 \mathrm{H}, \mathrm{dd}, J=8.0,1.2 \mathrm{~Hz}), 7.77-7.71(\mathrm{ArH}, 2 \mathrm{H}, \mathrm{m}), 7.59-7.46(\mathrm{ArH}$, 3H, m), 7.33-7.26 (ArH, 2H, m), 7.17-7.06 (ArH, 5H, m), 7.02-7.00 (ArH, 2H, m), $6.92(\mathrm{ArH}$, $1 \mathrm{H}, \mathrm{d}, J=8.1 \mathrm{~Hz}$ ), 6.87-6.84 (ArH, 2H, m), 6.39 (Benzylamine NH, 1H, t, $J=7.8 \mathrm{~Hz}), 5.65$ ( $\left.\mathrm{CH}_{2}(1), 1 \mathrm{H}, \mathrm{d}, J=15.3 \mathrm{~Hz}\right), 4.68\left(-\mathrm{CH}_{2}(1), 1 \mathrm{H}, \mathrm{d}, J=15.3 \mathrm{~Hz}\right), 4.53-4.46\left(-\mathrm{CH}_{2}(2), 1 \mathrm{H}, \mathrm{m}\right)$, 4.28-4.23 $\left(-\mathrm{CH}_{2}(2), 1 \mathrm{H}, \mathrm{m}\right) ;{ }^{13} \mathrm{C}$ NMR $75 \mathrm{MHz}\left(\mathrm{CDCl}_{3}, \delta \mathrm{ppm}\right): 167.2,162.1,156.0,147.0$, $137.3,136.5,134.5,134.4,133.5,130.3,129.9,129.3,128.6(2 \mathrm{C}), 128.4(2 \mathrm{C}), 127.9,127.8$, 127.6(2C), 127.5, 127.4, 127.3(2C), 127.2, 127.1, 121.1, 48.9, 44.1.

\section{General procedure for products $2 \mathrm{c}-\mathrm{f}$}

( $2.0 \mathrm{~g}, 7.02 \mathrm{mmol}$ ) of compound 1 was dissolved in dimethylformamide (DMF, 8mL). Methyl esters of various amino acids such as Leu, Phe, Ile and Val obtained from their hydrochloride (42.12 mmol) were added to the former solution followed by addition of DCC (4.34 g, 21.06 mmol) and HOBT (1.90 g, $14.04 \mathrm{mmol})$ in an ice-cold (solvent) solution. ${ }^{16}$ The reaction mixture was stirred at room temperature for 1 day. The precipitated dicyclohexylurea (DCU) was filtered off. The filtrate was diluted with ethyl acetate. The organic layer was washed with $1 \mathrm{~N} \mathrm{HCl}$ $(3 \times 30 \mathrm{~mL})$, brine, $1 \mathrm{M} \mathrm{Na}_{2} \mathrm{CO}_{3}$ solution $(3 \times 30 \mathrm{~mL})$ and then again with brine. The solvent was dried over anhydrous $\mathrm{Na}_{2} \mathrm{SO}_{4}$ and evaporated in vacuo, giving a light yellow gum. The products were purified by column chromatography over silica gel (ethylacetate-petroleum ether). The final compounds were fully characterized by $300 \mathrm{MHz}{ }^{1} \mathrm{H}$ NMR spectroscopy, $75 \mathrm{MHz}{ }^{13} \mathrm{C}$ NMR spectroscopy, IR spectroscopy. Single crystals were grown from a mixture of ethyl acetatepetroleum ether (for 2c) and chloroform-petroleum ether (for 2d) by slow evaporation and were stable at room temp.

2c. Elemental analysis calcd for $\mathrm{C}_{29} \mathrm{H}_{35} \mathrm{~N}_{3} \mathrm{O}_{6}(521.61) \mathrm{C}, 66.78 ; \mathrm{H}, 6.76 ; \mathrm{N}, 8.05 \%$. Found: $\mathrm{C}$,

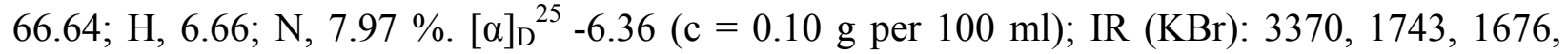
$1527 \mathrm{~cm}^{-1} ;{ }^{1} \mathrm{H}$ NMR $300 \mathrm{MHz}\left(\mathrm{CDCl}_{3}, \delta \mathrm{ppm}\right): 8.30(\mathrm{ArH}, 1 \mathrm{H}, \mathrm{d}, J=7.5 \mathrm{~Hz}), 7.87(\mathrm{ArH}, 1 \mathrm{H}, \mathrm{d}$, $J=7.5 \mathrm{~Hz}), 7.57(\mathrm{ArH}, 1 \mathrm{H}, \mathrm{t}, J=7.5 \mathrm{~Hz}), 7.44(\mathrm{ArH}, 2 \mathrm{H}, \mathrm{m}), 7.32(\mathrm{ArH}, 2 \mathrm{H}, \mathrm{m}), 6.80(\mathrm{ArH}$, 
$1 \mathrm{H}, \mathrm{d}, J=7.5 \mathrm{~Hz}), 6.58(\mathrm{Leu} \mathrm{NH}, 1 \mathrm{H}, \mathrm{d}, J=7.8 \mathrm{~Hz}), 5.29\left(\mathrm{C}^{\alpha} \mathrm{H}\right.$ of Leu $\left.(1), 1 \mathrm{H}, \mathrm{m}\right), 4.79\left(\mathrm{C}^{\alpha} \mathrm{H}\right.$ of Leu(2), 1H, m), $3.75\left(\mathrm{Leu}(1)-\mathrm{OCH}_{3}, 3 \mathrm{H}, \mathrm{s}\right), 3.52\left(\mathrm{Leu}(2)-\mathrm{OCH}_{3}, 3 \mathrm{H}, \mathrm{s}\right), 1.61\left(\mathrm{C}^{\beta} \mathrm{Hs}\right.$ of Leu (1) and Leu (2), 4H, m), 1.04-0.97 ( $\mathrm{C}^{\gamma} \mathrm{Hs}$ of Leu (1) and Leu (2), 2H, m), 0.85-0.72 ( $\mathrm{C}^{\delta} \mathrm{Hs}$ of Leu (1) and Leu (2), 12H, m); ${ }^{13} \mathrm{C}$ NMR $75 \mathrm{MHz}\left(\mathrm{CDCl}_{3}, \delta \mathrm{ppm}\right): 173.1,170.7,167.2,165.7$, 146.3, 133.3, 132.5 (2C), 132.2, 131.8 (2C), 131.4, 129.5, 125.6, 124.9, 123.8, 121.2, 52.6, 51.9, $51.6,51.2,40.8,37.9,25.3,24.9,23.1,22.8,22.7,21.5$.

2d. Elemental analysis calcd for $\mathrm{C}_{35} \mathrm{H}_{31} \mathrm{~N}_{3} \mathrm{O}_{6}(589.64) \mathrm{C}, 71.29 ; \mathrm{H}, 5.30 ; \mathrm{N}, 7.12 \%$. Found: $\mathrm{C}$, 71.17; H, 5.14; N, $7.01 \%$. $[\alpha]_{\mathrm{D}}{ }^{25}-27.4(\mathrm{c}=0.10 \mathrm{~g}$ per $100 \mathrm{ml})$; IR $(\mathrm{KBr}): 3322,1737,1650$, $1529 \mathrm{~cm}^{-1} ;{ }^{1} \mathrm{H}$ NMR $300 \mathrm{MHz}\left(\mathrm{CDCl}_{3}, \delta \mathrm{ppm}\right): 8.11(\mathrm{ArH}, 1 \mathrm{H}, \mathrm{m}), 7.81(\mathrm{ArH}, 1 \mathrm{H}, \mathrm{d}, J=7.5$ $\mathrm{Hz})$, 7.69 (ArH, 1H, d, $J=6.9 \mathrm{~Hz}), 7.52(\mathrm{ArH}, 2 \mathrm{H}, \mathrm{t}, J=7.5 \mathrm{~Hz}), 7.28-7.02(\mathrm{ArH}, 13 \mathrm{H}, \mathrm{m}), 6.35$ (Phe NH, 1H, d, J = 7.8 Hz), $5.32\left(\mathrm{C}^{\alpha} \mathrm{H}\right.$ of Phe (1), 1H, m), $4.99\left(\mathrm{C}^{\alpha} \mathrm{H}\right.$ of Phe (2), 1H, m), 3.76 (Phe (1) $\left.-\mathrm{OCH}_{3}, 3 \mathrm{H}, \mathrm{s}\right), 3.58$ (Phe (2) $\left.-\mathrm{OCH}_{3}, 3 \mathrm{H}, \mathrm{s}\right), 3.21\left(\mathrm{C}^{\beta} \mathrm{Hs}\right.$ of Phe (1) and Phe (2), 4H, m); ${ }^{13} \mathrm{C}$ NMR $75 \mathrm{MHz}\left(\mathrm{CDCl}_{3}, \delta \mathrm{ppm}\right): 171.7,169.7,166.9,165.5,151.7,145.9,137.1,136.6,136.5$, 133.0, 132.8, 132.4, 131.8, 131.5 (2C), 131.0 (2C), 129.3 (2C), 129.2, 128.6, $128.4(2 \mathrm{C}), 128.2$, $126.6,125.5,124.9,123.6,121.5,53.9,53.8,52.5,52.0,37.2,35.0$.

2e. Elemental analysis calcd for $\mathrm{C}_{29} \mathrm{H}_{35} \mathrm{~N}_{3} \mathrm{O}_{6}(521.61) \mathrm{C}, 66.78 ; \mathrm{H}, 6.76 ; \mathrm{N}, 8.05 \%$. Found: $\mathrm{C}$, 66.68; H, 6.64; N, $7.94 \%$. ${ }^{1} \mathrm{H}$ NMR $300 \mathrm{MHz}\left(\mathrm{CDCl}_{3}, \delta \mathrm{ppm}\right): 8.06(\mathrm{ArH}, 1 \mathrm{H}, \mathrm{d}, J=7.8 \mathrm{~Hz})$, 7.85 (ArH, 1H, d, $J=7.5 \mathrm{~Hz}$ ), 7.56 (ArH, 2H, m), 7.43 (ArH, 1H, m), 7.33 (ArH, 2H, m), 6.84 (ArH, 1H, d, $J=7.2 \mathrm{~Hz}$ ), 6.59 (Ile NH, 1H, d, $J=7.8 \mathrm{~Hz}$ ), 5.02 (C ${ }^{\alpha} \mathrm{H}$ of Ile (1), 1H, m), 4.67 $\left(\mathrm{C}^{\alpha} \mathrm{H}\right.$ of Ile(2), 1H, m), 3.72 (Ile (1) $\left.-\mathrm{OCH}_{3}, 3 \mathrm{H}, \mathrm{s}\right), 3.58$ (Ile (2) $\left.-\mathrm{OCH}_{3}, 3 \mathrm{H}, \mathrm{s}\right), 1.65-1.63$ $\left(\mathrm{C}^{\beta} \mathrm{Hs}\right.$ of Ile (1) and Ile (2), 2H, m), 1.40-1.20 ( $\mathrm{C}^{\gamma} \mathrm{Hs}$ of Ile (1) and Ile (2), 10H, m), 0.95-0.88 $\left(\mathrm{C}^{\delta} \mathrm{Hs}\right.$ of Ile (1) and Ile (2), $\left.6 \mathrm{H}, \mathrm{m}\right) ;{ }^{13} \mathrm{C}$ NMR $75 \mathrm{MHz}\left(\mathrm{CDCl}_{3}, \delta \mathrm{ppm}\right): 173.2,171.9,167.3$, 166.4, 153.1, 148.8, 134.2(2C), 133.4, 132.1, 131.4, 131.1, 129.9, 129.7, 129.1, 128.3, 123.6, $56.7,55.9,52.3,51.9,39.2,37.8,25.1,24.8,15.2,14.1,12.2,11.4$.

2f. Elmental analysis calcd for $\mathrm{C}_{27} \mathrm{H}_{31} \mathrm{~N}_{3} \mathrm{O}_{6}(493.56) \mathrm{C}, 65.71 ; \mathrm{H}, 6.33 ; \mathrm{N}, 8.51 \%$. Found: $\mathrm{C}$, 65.58; H, 6.21; N, $8.44 \% .{ }^{1} \mathrm{H}$ NMR $300 \mathrm{MHz}\left(\mathrm{CDCl}_{3}, \delta \mathrm{ppm}\right): 8.30(\mathrm{ArH}, 1 \mathrm{H}, \mathrm{d}, J=7.5 \mathrm{~Hz})$, $7.90(\mathrm{ArH}, 1 \mathrm{H}, \mathrm{d}, J=7.5 \mathrm{~Hz}), 7.80(\mathrm{ArH}, 2 \mathrm{H}, \mathrm{t}, J=7.8 \mathrm{~Hz}), 7.67-7.46(\mathrm{ArH}, 4 \mathrm{H}, \mathrm{m}), 7.10$ (Val $\mathrm{NH}, 1 \mathrm{H}, \mathrm{d}, J=7.8 \mathrm{~Hz}), 5.21\left(\mathrm{C}^{\alpha} \mathrm{H}\right.$ of $\left.\mathrm{Val}(1), 1 \mathrm{H}, \mathrm{m}\right), 4.70\left(\mathrm{C}^{\alpha} \mathrm{H}\right.$ of Val $\left.(2), 1 \mathrm{H}, \mathrm{m}\right), 3.72(\mathrm{Val}$ (1) $\left.-\mathrm{OCH}_{3}, 3 \mathrm{H}, \mathrm{s}\right), 3.48$ (Val (2) $\left.-\mathrm{OCH}_{3}, 3 \mathrm{H}, \mathrm{s}\right), 2.09-2.03\left(\mathrm{C}^{\beta} \mathrm{Hs}\right.$ of $\mathrm{Val}(1)$ and $\left.\mathrm{Val}(2), 2 \mathrm{H}, \mathrm{m}\right)$, 1.18-1.03 ( $\mathrm{C}^{\gamma} \mathrm{Hs}$ of Val (1) and Val (2), $\left.12 \mathrm{H}, \mathrm{m}\right) ;{ }^{13} \mathrm{C} \mathrm{NMR} 75 \mathrm{MHz}\left(\mathrm{CDCl}_{3}, \delta \mathrm{ppm}\right)$ : 172.0, 167.4, 166.8, 161.3, 149.2, 143.4, 135.4, 134.6, 132.5, 131.8, 131.6, 129.8, 128.7, 124.7, 123.9, $120.3,108.7,57.4,57.2,52.1,52.0,31.2,30.6,18.7,18.2,17.7,17.4$.

\section{General procedure for products $5 a$ and $5 b$}

$\mathbf{5 a}$ and $\mathbf{5 b}$ were produced following the similar procedure as that of $\mathbf{2 a}$ and $\mathbf{2} \mathbf{b}$ described previously. Here 1 was coupled with methyl $m$-aminobenzoate and $p$-nitroaniline in presence of DCC to produce $\mathbf{5 a}$ and $\mathbf{5 b}$ respectively (Table 1 , Scheme 2 ).

5a. Elemental analysis calcd for $\mathrm{C}_{23} \mathrm{H}_{16} \mathrm{~N}_{2} \mathrm{O}_{5}(400.39) \mathrm{C}, 69.00 ; \mathrm{H}, 4.03 ; \mathrm{N}, 7.00 \%$. Found: $\mathrm{C}$, 68.85; H, 3.90; N, $6.94 \%$. IR (KBr): 3345, 1715, 1602, 1531, $1488 \mathrm{~cm}^{-1} .{ }^{1} \mathrm{H}$ NMR $300 \mathrm{MHz}$ (DMSO-d ${ }_{6}, \delta$ ppm): 10.75 (m-ABA NH, 1H, s); 8.25 (ArH, 1H, s); 7.91-7.78 (ArH, 6H, m); 7.70- 
$7.53(\mathrm{ArH}, 4 \mathrm{H}, \mathrm{m}) ; 7.40(\mathrm{ArH}, 1 \mathrm{H}, \mathrm{t}, J=7.8 \mathrm{~Hz}) ; 3.78\left(\mathrm{~m}-\mathrm{ABA}-\mathrm{OCH}_{3}, 3 \mathrm{H}, \mathrm{s}\right) ;{ }^{13} \mathrm{C}$ NMR 75 MHz (DMSO-d ${ }_{6}, \delta$ ppm): 167.0 (2C), 166.1, 165.3, 139.5, 135.0 (2C), 133.7, 131.6, 131.5 (2C), 130.2 (2C), 130.1, 129.2, 129.1, 128.9, 124.6, 124.4, 123.7(2C), 120.6, 52.3.

5b. Elemental analysis calcd for $\mathrm{C}_{21} \mathrm{H}_{13} \mathrm{~N}_{3} \mathrm{O}_{5}(387.35) \mathrm{C}, 65.12 ; \mathrm{H}, 3.38 ; \mathrm{N}, 10.85 \%$. Found: $\mathrm{C}$, 65.01; H, 3.45; N, 10.71\%. IR (KBr): 3337, 1708, 1496, $1459 \mathrm{~cm}^{-1} .{ }^{1} \mathrm{H} \mathrm{NMR} 300 \mathrm{MHz}\left(\mathrm{CDCl}_{3}\right.$, $\delta$ ppm): $8.18(\mathrm{ArH}, 1 \mathrm{H}, \mathrm{dd}, J=7.8,1.5 \mathrm{~Hz}), 7.95-7.87(\mathrm{ArH}$ and $p$-NA NH, 4H,m), 7.80-7.75 $(\mathrm{ArH}, 3 \mathrm{H}, \mathrm{m}), 7.70-7.46(\mathrm{ArH}, 2 \mathrm{H}, \mathrm{m}), 7.58-7.34(\mathrm{ArH}, 3 \mathrm{H}, \mathrm{m}) ;{ }^{13} \mathrm{C} \mathrm{NMR} 75 \mathrm{MHz}\left(\mathrm{CDCl}_{3}, \delta\right.$ ppm): 167.3 (2C), 166.4, 133.9 (2C), 132.6(2C), 132.1, 131.7(2C), 131.5, 130.0(2C), 129.0, $128.8,126.6,124.6,123.4(2 \mathrm{C}), 118.5,109.8$.

\section{FT-IR spectroscopy}

IR spectra was examined in Perkin Elmer - 782 model spectrophotometer.The solid- state FT-IR measurements were performed using the $\mathrm{KBr}$ disk technique.

\section{NMR experiments}

All ${ }^{1} \mathrm{H}$ NMR and ${ }^{13} \mathrm{C}$ NMR study was recorded on a Bruker Avance 300 model spectrometer operating at 300, $75 \mathrm{MHz}$ respectively. The peptide concentration was in the range 1-10 $\mathrm{mM}$ in $\mathrm{CDCl}_{3}$ and $\mathrm{d}_{6}$-DMSO for ${ }^{1} \mathrm{H}$ NMR and $30-40 \mathrm{mM}$ in $\mathrm{CDCl}_{3}$ and $\mathrm{d}_{6}$-DMSO for ${ }^{13} \mathrm{C}$ NMR. Solvent titration experiments were carried out at a concentration of $10 \mathrm{mM}$ in $\mathrm{CDCl}_{3}$ with gradual addition of $\mathrm{d}_{6}$-DMSO from $0-8.1 \% \mathrm{v} / \mathrm{v}$ approximately.

\section{Circular Dichroism Spectroscopy}

A methanolic solution of peptide 2c and 2d (1.5 $\mathrm{mM}$ as final concentration) was used for obtaining the spectra. Far- UV CD measurement was recorded at $25^{\circ} \mathrm{C}$ with a $0.5 \mathrm{sec}$ averaging time, a scan speed of $50 \mathrm{~nm} / \mathrm{min}$, using a JASCO spectropolarimeter (J 720 model) equipped with a $0.1 \mathrm{~cm}$ pathlength cuvette. The measurement was taken at $0.2 \mathrm{~nm}$ wavelength interval, 2.0 $\mathrm{nm}$ spectral bandwidth and five sequential scans were recorded for the sample.

\section{$\mathrm{X}$-ray crystal analysis}

2c. $\mathrm{C}_{29} \mathrm{H}_{35} \mathrm{~N}_{3} \mathrm{O}_{6}, \mathrm{M}=521.61$, orthorhombic, $\mathrm{Z}=4$, spacegroup $\mathrm{P} 2{ }_{1}{ }_{2} 2_{1}, \mathrm{a}=8.7113(2), \mathrm{b}=$

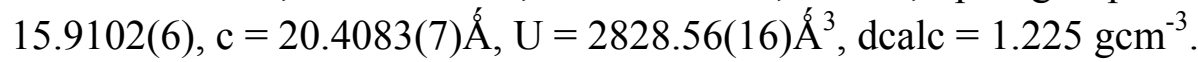

2d. $\mathrm{C}_{35} \mathrm{H}_{31} \mathrm{~N}_{3} \mathrm{O}_{6}, \mathrm{M}=589.63$, monoclinic, $\mathrm{Z}=2$, spacegroup $\mathrm{P} 2_{1}, \mathrm{a}=9.0115(5), \mathrm{b}=16.6627(6)$, $\mathrm{c}=10.4293(6) \AA ̊ \AA, \beta=109.916(6)^{\circ}, \mathrm{U}=1427.36(13) \AA^{3}, \mathrm{dcalc}=1.330 \mathrm{gcm}^{-3} ; 7820$ and 5862 independent data for $2 \mathrm{c}$ and $2 \mathbf{d}$ respectively were collected with $\mathrm{MoK} \alpha$ radiation at $150 \mathrm{~K}$ using the Oxford Diffraction X-Calibur CCD System. The crystals were positioned at $50 \mathrm{~mm}$ from the CCD. 321 frames were measured with a counting time of 10s. Data analyses were carried out with the CrysAlis program. ${ }^{9}$ The structures were solved using direct methods with the Shelxs97 program. ${ }^{10}$ The non-hydrogen atoms were refined with anisotropic thermal parameters. The hydrogen atoms bonded to carbon were included in geometric positions and given thermal 
parameters equivalent to 1.2 times those of the atom to which they were attached. The structures were refined on $\mathrm{F}^{2}$ using Shelx197 ${ }^{10}$ to respectively R1 0.0440 and 0.0548 ; wR2 0.0987 and 0.1403 for 5103 and 4656 reflections with $\mathrm{I}>2 \sigma(\mathrm{I})$. Crystallographic data have been deposited at the Cambridge Crystallographic data Centre with reference number CCDC 699562 and 699563 for peptides $\mathbf{2 c}$ and $\mathbf{2 d}$ respectively.

\section{Acknowledgements}

PK thanks UGC, New Delhi for providing Project Fellowship. AD and SK would like to thank CSIR, New Delhi, India, for providing senior research fellowship. The financial assistance of UGC, New Delhi is acknowledged [Major Research Project, No.32-190/2006 (SR)]. We thank EPSRC and the University of Reading, UK for funds for Oxford Diffraction X-Calibur CCD diffractometer.

\section{References and Notes}

1. (a) Model, E. U. S. Patent 4,327,024, 1982. (b) Model, E. U. S. Patent 3,971,805, 1976. (c) Iqbal, A.; Herren, F.; Wallquist, O. High Performance Pigments (Ed. Smith, H. M.); WileyVCH, Germany, 2002; Ch. 15, pp. 231.

2. Bäbler, F. U. S. Patent 6,902,613 B2, 2005.

3. Kawamura, M.; Higashi, M. Journal of Inclusion Phenomena and Macrocyclic Chemistry. 2005, 51, 11.

4. Huang, C. Y.; Yang, Y. S. Protein Expression and Purification. 2005, 40, 203.

5. Zhang, Z.; Uth, S.; Sandman, D. J.; Foxman, B. M. Journal of Physical Organic Chemistry. 2004, 17, 769.

6. (a) Mattos, C.; Petsko, G. A.; Karplus, M. J. Mol. Biol. 1994, 238, 733; (b) Wilmont, C. M.; Thornton, J. M. J. Mol. Biol. 1988, 203, 221; (c) Kabsch, W., Sander, C. Biopolymers 1983, $22,2577$.

7. (a) Cluzeau, J.; Lubell, W. D. Biopolymers 2005, 80, 98. (b) Belvisi, L.; Colombo, L.; Manzoni, L.; Potenza, D.; Scolastico, C. Synlett 2004, 1449; (c) Lelais, G.; Seebach, D. Biopolymers 2004, 76, 206; (d) Hanessian, S.; McNaughtonSmith, G.; Lombart, H. G.; Lubell, W. D. Tetrahedron 1997, 53, 12789; (d) Nagai, U.; Sato, K. Tetrahedron Lett. 1985, 26, 647; (e) Genin, M. J.; Mishra, R. K.; Johnson, R. L. J. Med. Chem. 1993, 36, 3481; (f) Genin, M. J.; Johnson, R. L. J. Am. Chem. Soc. 1992, 114, 8778; (g) James, G. L.; Goldstein, J. L.; Brown, M. S.; Rawson, T. E.; Somers, T. C.; McDowell, R. S.; Crowley, C. W.; Lucas, B. K.; Levinson, A. D.; Marsters, Jr. J. C. Science 1993, 260, 1937; (h) Saragovi, H. U.; Fitzpatrick, D.; Raktabutr, A.; Nakanishi, H.; Khan, M.; Greene, M. I. Science 1991, 253, 792; (i) Baca, M.; Alewood, P. F.; Kent, S. B. H. Protein Sci. 1993, 2, 1085; (j) Belvisi, L.; 
Bernardi, A.; Manzoni, L.; Potenza, D.; Scolastico, C. Eur. J. Org. Chem. 2000, 2563; (k) Belvisi, L.; Gennari, C.; Madder, A.; Mielgo, A.; Potenza, D.; Scolastico, C. Eur. J. Org. Chem. 2000, 695; (1) Belvisi, L.; Gennari, C.; Mielgo, A.; Potenza, D.; Scolastico, C. Eur. J. Org. Chem. 1999, 389; (m) Franz, A. H.; Gross, P. H.; Samoshin, V. V. Arkivoc 2008 (i), 271.

8. Wiklund, P.; Romero, I.; Bergman, J. Org. Biomol. Chem. 2003, 1, 3396.

9. CrysAlis, (2006) Oxford Diffraction Ltd., Abingdon, U.K.

10. Sheldrick, G. M. Shelxs97 and Shelx197, Programs for Crystallographic solution and refinement, Acta Cryst. 2008, A64, 112.

11. Lewis, P. N.; Momany, F. A.; Sheraga, H. A. Biochim. Biophys. Acta. 1973, 303, 211.

12. Dutt, A.; Drew, M. G. B.; Pramanik, A. Tetrahedron 2005, 61, 11163.

13. (a) Crisma, M.; Valle, G.; Toniolo, C.; Prasad, S.; Balaji Rao, R.; Balaram, P. Biopolymers 1995, 35, 1; (b) Bosch, R.; Jung, G.; Voges, K. P.; Winter, W. Liebigs Ann. Chem. 1984, 1117; (c) Jung, G.; Bruckner, H.; Bosch, R.; Winter, W., Schaal, H.; Strale, J. Liebigs Ann. Chem. 1983, 1608.

14. Dutt, A.; Dutta, A.; Mondal, R.; Spencer, E. C.; Howard, J. A. K.; Pramanik, A. Tetrahedron 2007, 63, 10282.

15. Ressurreicão, A. S. M.; Bordessa, A.; Civera, M.; Belvisi, L.; Gennari, C.; Piarulli, U. J. Org. Chem. 2008, 73, 652.

16. Bodansky, M.; Bodansky, A. The Practice of Peptide Synthesis; Springer-Verlag: New York, 1984; pp 1. 